\title{
At Last, a Sensitive Method to Detect Incipient Systolic Dysfunction!
}

\author{
Carlos Eduardo Suaide Silva ${ }^{10}$ \\ Diagnósticos da América SA, ${ }^{1}$ São Paulo, SP - Brazil \\ Short Editorial related to the article: The Use of Two-Dimensional Strain Measured by Speckle Tracking in the Identification of Incipient \\ Ventricular Dysfunction in HIV-Infected Patients on Antiretroviral Therapy, Untreated HIV Patients and Healthy Controls
}

Left ventricular systolic function evaluation has always been one of the main attributions of echocardiography. The degree of ventricular systolic dysfunction is an important predictor of outcome for a large number of diseases, including ischemic heart disease, cardiomyopathy, valvular heart disease, and congenital heart disease. In this area, the ejection fraction has been sovereign for many decades, but despite being a parameter that can, in most cases, inform the real state of global ventricular function, in many situations it may be normal in the presence of evident systolic or diastolic dysfunction.

Known clinical examples are the several cases of heart failure with preserved ejection fraction (HFpEF) or patients with hypertrophic cardiomyopathy, among others. For this reason, an index that can identify early ventricular dysfunction that is not connected with the ejection fraction has been sought for a long time.

Myocardial deformation evaluation by echocardiography emerged with the strain and strain rate techniques, still derived from tissue Doppler, which was developed at the Norwegian University of Science and Technology in Trondheim, Norway, approximately twenty years ago. ${ }^{1,2}$ In 2004, we had already demonstrated the presence of incipient systolic dysfunction in patients with the indeterminate form of Chagas disease using this technique. ${ }^{3}$

\section{Keywords}

Heart Failure; Ventricular Dysfunction Left; Cardiomyopathy, Hypertrophic; HIV; Antiretroviral Therapy Highly Active; Myocardial Contraction; Echocardiography/methods.

Mailing Address: Carlos Eduardo Suaide Silva •

Rua Xavier Gouveia, 241, Apt 92. Postal Code 04610-010, São Paulo, SP - Brazil E-mail: csuaide@cardiol.br

DOI: $10.5935 / a b c .20190198$
Later, in 2006, the speckle tracking technique appeared, which quantifies myocardial deformation by two-dimensional echo and does not depend on the insonation angle (a limitation of the prior technique). ${ }^{4}$ This technique has advanced to the present day and allows measuring the longitudinal, radial and circumferential deformation of the several myocardial segments (strain). The mean value of the percentage of longitudinal deformation of each segment is what we call the global longitudinal strain (GLS) and this index has shown to be an excellent parameter for systolic function evaluation, which is sensitive enough to detect incipient impairment when the ejection fraction is still normal and has a higher prognostic value than EF in many clinical situations. ${ }^{5-7}$

In this issue of the Brazilian Archives of Cardiology, Dr. Ronaldo Campos Rodrigues presents us with an excellent work, in which left ventricular systolic function was assessed by quantifying GLS in HIV-positive patients, with and without antiretroviral therapy, compared with a control group. ${ }^{8}$ It was observed that GLS values were significantly lower in infected individuals than in control ones, regardless of whether or not they were undergoing treatment. All of them had normal ejection fraction and the only group with abnormal GLS (less than -18\%) was that of infected individuals without treatment. Their findings demonstrate the high sensitivity of this echocardiographic parameter in detecting incipient systolic dysfunction, which leads us to think that treatment must decrease myocardial aggression by the virus. Early systolic dysfunction was also found by Mendes et al., ${ }^{9}$ in a similar group.

These and other studies point to a paradigm shift in the study of ventricular function. I believe that soon, cardiologists will not be satisfied with the value of the ejection fraction alone but will also require the value of GLS for a deeper and more accurate assessment of ventricular systolic function. 


\section{References}

1. Heimdal A. Doppler based ultrasound imaging methods for noninvasive assessment of tissue viability [thesis]. Trondheim: Norwegian Faculty of Medicine/University of Science and Technology; 1999.

2. Støylen A. Strain rate imaging of the left ventricle by ultrasound. Feasibility, clinical validation and physiological aspects [thesis]. Trondheim: Norwegian faculty of Medicine/University of Science and Technology; 2001.

3. Silva CES, Ferreira LDC, Peixoto LB, Monaco CG, Gil MA, Ortiz J et al. Avaliação da contratilidade segmentar na doença de Chagas utilizando a integral do gradiente intramiocárdico de velocidade (strain miocárdico) obtida pela ecocardiografia com Doppler tecidual. Arq Bras Cardiol 2005;84(5):285-91.

4. Amundsen BH, Helle-Valle T, Edvardsen T, Torp H, Crosby J, et al. Noninvasive Myocardial Strain Measurement by Speckle Tracking Echocardiography. Validation Against Sonomicrometry and Tagged Magnetic Resonance Imaging. J Am Coll Cardiol 2006;47(4):789-93.
5. Park JJ, Park JB, Park JH, Cho GY. Global longitudinal strain to predict mortality in patients with acute heart failure. J Am Coll Cardiol. 2018;71(18):1947-57.

6. Sengeløv M, Jørgensen PG, Jensen JS, Bruun NE, Olsen FJ, Fritz-Hansen T, et al. Global longitudinal strain is a superior predictor of all-cause mortality in heart failure with reduced ejection fraction. JACC Cardiovasc Imaging. $2015 ; 8(12): 1351-9$

7. Maia RJC, Brandão SCS, Brandão DC, Leite J, Parente GB, Pinheiro F, et al Global Longitudinal Strain Predicts Poor Functional Capacity in Patients with Systolic Heart Failure. Arq Bras Cardiol. 2019; 113(2):188-94.

8. Rodrigues RC, Azevedo KML, Moscavitch SD, Setubal S, Mesquita CT. O Uso do Strain Bidimensional Obtido pelo Speckle Tracking na Identificação da Disfunção Ventricular Incipiente em Pacientes Infectados pelo HIV em Uso de Terapia Antirretroviral, Pacientes HIV não Tratados e Controles Saudáveis. Arq Bras Cardiol. 2019; 113(4):737-745.

9. Mendes L, Silva D, Miranda C, Sá J, Duquec L. Impact of HIV infection on cardiac deformation. Rev Port Cardiol. 2014;33(9):501-9. 